\section{The continued de-development of the Palestinian economy in the post-Oslo period}

\section{Osama Hamed}

$\mathrm{T}$

he Oslo Accords, reached in 1993 and supposed to govern Palestinian-Israeli relations as from 1994, allowed Israel to have direct control over large areas of the West Bank and Gaza Strip (WBGS). They also gave Israel control over WBGS borders with the rest of the world, WBGS underground water resources, and administration of the collection of most WBGS tax revenues. Such control has severely constrained WBGS economic development in the post-Oslo period, resulting in continued dependence of the Palestinian economy on Israel.

The Oslo Accords kept 70 percent of the West Bank and (until 2006) 40 percent of the Gaza Strip under direct Israeli military control. The remaining areas of the WBGS, where the Palestinian Authority (PA) was given control over civil affairs, are not contiguous. ${ }^{1}$ Areas controlled directly by Israel include East Jerusalem and the West Bank shores of the Dead Sea, which are essential for the development of the Palestinian tourism sector. They also include the Jordan valley, which has some of the most fertile land in the WBGS. Under the Oslo Accords, any investment project in areas controlled directly by Israel require Israeli approval - rarely granted limiting investment in infrastructure in the post-Oslo period despite the availability of foreign-aid funds for such investment. Israel's control over large areas of the West Bank has allowed it to continue confiscating Palestinian land to build and expand Israeli settlements, leading to a significant decrease in the area of Palestinian cultivated land and in agricultural value-added. To facilitate land confiscation, Israeli military authorities have maintained the land registration freeze that was put in place soon after Israeli occupation of the WBGS in $1967 .^{2}$

Continued Israeli control over WBGS borders and air space has prevented the PA from building a seaport in the Gaza Strip and expanding the small airport built in the Gaza Strip to allow cargo transport. ${ }^{3}$ This, in turn, has forced the WBGS to continue to rely upon Israeli ports for its exports and imports, where goods destined for the WBGS are subject to excessive inspections and delays. The resulting extra costs have forced Palestinian businesses to buy Israeli-made products or products imported by Israeli firms rather than directly importing from other countries. This has continued WBGS trade dependence on Israel.

In the post-Oslo period, Israel has maintained its control over West Bank aquifers, which account for most of WBGS water resources. The 1967 ban on drilling new wells by Palestinians remains in place, ${ }^{4}$ as does the policy of diverting most of the water pumped from the aquifers to Israeli users. The lack of an adequate supply of water has had a devastating effect on the Palestinian agricultural sector, effectively wiping out the citrus industry which before 1967 accounted for a large share of the WBGS agricultural value-added. It has limited household water consumption to 65 liters per capita per day, compared with 280 for Israel. ${ }^{5}$

Israel has continued to control the collection of most WBGS revenues despite handing the responsibility of delivering public services in the WBGS to the PA.

The Oslo Accords allow Israel to collect tariffs and value-added taxes on Palestinian imports without providing an effective mechanism to transfer the tax revenues to the PA. The tax transfer mechanism called for by the Oslo Accords covers tariffs on direct Palestinian imports from outside Israel, and value-added taxes on Palestinian imports from Israel. To reclaim these revenues, the Accords require the PA to obtain individual receipts from those who paid the taxes. This has resulted in a significant tax leakage to Israel because some Palestinian merchants forget to submit their receipts and others do not do so to reduce their income tax liability. It has also provided the Israeli government with enormous leverage in its relation with the PA. This became apparent after the 2000 intifada, when the Israeli government suspended the release of Palestinian tax revenues and began demanding political concessions as a condition for their release. Additionally, the Oslo Accords did not provide a mechanism for reimbursing the PA for tariffs generated by Palestinian indirect imports, which have been retained by the Israeli Treasury since $1967 .{ }^{6}$ The value of tariff revenues generated by WBGS indirect imports was estimated at 12 to 21 percent of WBGS GDP for the period 1967-1987. ${ }^{7}$ It is highly unlikely that indirect imports as a share of WBGS GDP have declined in view of the increase in the intensity of inspections and delays experienced by direct Palestinian imports in the post-Oslo period.

Israeli currency was required by the Oslo Accords to be legal tender in the WBGS, and it continued to be the main medium of exchange there in the post-Oslo period. Nevertheless, no mechanism was put in place to reimburse Palestinians for the seigniorage revenues generated as a result of using Israeli currency. This had also been the case in the period 1967-1993, when the Israeli-administered WBGS budget did not include seigniorage revenues generated as a result of the circulation of Israeli currency in the WBGS, estimated at 1.6 to 4.2 percent of WBGS GDP. ${ }^{8}$ The status of the Israeli currency as the main medium of exchange in the WBGS also gives Israel control over liquidity in the WBGS, providing the Israeli government with another tool to squeeze the Palestinian economy if such a squeeze serves its political goals. ${ }^{9}$

These topics are explored in the following sections. 


\section{Continued dependence on Israel in the period 1994-1999}

Internal and external closures

Israeli internal and external closures were first imposed on the WBGS during the 1990/1 Gulf W ar but were rarely used before 1994. Between 1994 and 1999, closures became common. An external closure effectively cuts the WBGS off from the rest of the world. It bans the movement of Palestinian goods and people between the WBGS and Israel, between the Gaza Strip and the West Bank because it involves some travel through Israel, and between East Jerusalem and the rest of the WBGS. Some external closures also prohibit the movement of Palestinian goods and people over the Jordan river bridges that link the West Bank to Jordan and the Rafah crossing point between the Gaza Strip and Egypt, the only links between the WBGS and the rest of the world that do not require crossing Israeli territory. An internal closure bans travel within the WBGS, confining Palestinians to the cities and villages they live in. Some internal closures in the period 1994-1999 covered the entire WBGS. Others were limited to particular regions, cities, or villages.

External closures between 1994-1999 prevented Palestinian workers from reaching their job sites in Israel. The decrease in spending resulting from the income loss suffered by these workers, who accounted for a large share of the WBGS labor force in the period 1994-2000, caused serious disruptions to economic activity in the WBGS. The ban on the movement of goods between the WBGS and the rest of the world prevented Palestinian exporters from delivering their products to customers in a timely fashion, putting future orders at risk and damaging perishable goods destined for export markets. It also disrupted the delivery of imported raw materials, upsetting production plans, and lowering capacity utilization rates of WBGS firms.

Internal closures that covered the whole WBGS effectively brought economic activity in the WBGS to a halt. Internal closures that were limited to particular regions damaged the economies of the regions and increased the cost of commerce between different parts of the WBGS by requiring some firms to make additional investments in storage facilities and forcing others to restrict their sales to their own regions.

Continued dependence on the Israeli labor market

Some of the constraints that limited investment in the period 1967-1993 were relaxed in the post-Oslo period. Administrative restrictions, such as bans on crops and manufacturing projects that competed with Israeli firms, ended following the 1994 establishment of the PA. Severe restrictions on the operation of non-Israeli banks in the WBGS, which had effectively left the Palestinians of the WBGS without banking services for much of the period 1967-1993, were also lifted after $1994 .{ }^{10}$ Despite the relaxation of these constraints, private investment in the post-Oslo period remained limited, even before the 2000 intifada. New investment in this period was limited mainly to the construction sector and manufacturing industries linked to Israel through sub-contracting arrangements, such as the apparel and the shoe industries. The lack of significant increase in private investment in the period 1994-1999 can be explained by continued political $\mathrm{u} n \mathrm{c}$ e $\mathrm{r}$ t a i n t y u n b a 1 a n c e d e c o $\mathrm{n}$ o $\mathrm{m}$ i $\mathrm{c}$ relationships with I s r a e $1, \quad$ a $\mathrm{n} \mathrm{d}$ disruptions caused by closures.

In view of limited investment, the private sector job creation capacity in

the post-Oslo period has not kept pace with the growth of the labor force, driven by a rapidly growing population and the return of tens of thousands of Palestinians to the WBGS following the establishment of the PA. Consequently, WBGS dependence on the Israeli labor market has continued. In addition, the limited job creation capacity of the private sector has put enormous pressure on PA leaders to expand the public sector far beyond the level needed to provide public services. In 1999, the number of WBGS workers in Israel reached 134,000, accounting for 20 percent of the labor force. In the same year, public sector employment - excluding municipalities and the United Nations Relief and Works Agency for Palestinian Refugees (UNRWA) reached 108,000, which represented 16 percent of total employment (Table 1). In contrast, the Israeli occupation administration of the WBGS had only 18,000 employees in 1992, accounting for 4.5 percent of the WBGS labor force. ${ }^{11}$ While some of the increase in public sector employment since 1994 can be justified by the need for public services that were either provided at inadequate levels or not provided at all by the occupation authorities, the expansion of public sector employment in this period has undoubtedly been excessive, resulting in overstaffing in most PA 


\section{institutions.}

\section{Trade dependence}

Limited private investment, along with the lack of direct access to international markets, allowed Israel to continue its dominance of Palestinian foreign trade. The Israeli shares of WBGS exports (about 85 percent) and imports (about 90 percent) in the period 1994-1999 were not significantly different from their levels in the period 1967-1993. The WBGS had a persistently large trade deficit in the period 1994-1999, as had been the case in the 1967-1993 period. Trade deficits before 1994 were financed mainly by the earnings of WBGS workers in Israel. In 1992, these earnings financed $\$ 930$ million of the $\$ 933$ million trade deficit. Foreign aid played an important role in financing the trade deficit in the period 1994-1999. In 1999, foreign aid financed 21.3 percent of the WBGS current account deficit while earnings of workers in Israel financed 32 percent (see Table 2).

\section{Economic collapse after 2000}

Disruptions caused by closures and other Israeli measures

Following the 2000 intifada, the Israeli government curtailed the flow of Palestinian workers to the Israeli labor market. By 2002, the number of Palestinian workers in Israel was down to 50,000, and has remained at about this level since then (Table 1). The WBGS economy, which was suffering other adverse economic shocks caused by other Israeli punitive measures, was in no position to absorb the Palestinian workers who lost their jobs in Israel.

In 2001, the Israeli government suspended the regular transfer of tax revenues collected by its treasury from Palestinians on the PA's behalf. The suspension decreased PA revenues drastically; taxes collected by Israel accounted for about 50 percent of total PA revenues before the intifada (Table 3). While foreign aid has provided substantial support to the PA budget since 2001, this support has not been sufficient to maintain services provided by the PA at the pre-intifada level. ${ }^{12}$

Israel has conducted frequent heavy-handed military raids into WBGS cities and villages since the 2000 intifada, damaging infrastructure, business establishments, and private homes. External closures have been tightened in the post-intifada period. Restrictions on the movement of Palestinian people and goods between the WBGS and the outside world have become stricter, the border crossings between the WBGS and Jordan and Egypt have been closed more frequently, and Palestinian exports and imports have been subject to more restrictions as well. Internal closures have also become more severe. In the Gaza Strip, Israel erected barricades and roadblocks that had effectively divided the region into three areas before withdrawing from there in 2006. In the West Bank, entrances to cities and most villages were blocked with earthen mounds. This effectively ended the movement of vehicles between Palestinian population centers. Palestinians traveling outside their cities and villages have to pass through gates controlled by Israeli soldiers (usually a slow process), or try bypassing Israeli gates and risk being shot by Israeli soldiers. Trucks traveling to a city must unload their cargo at Israeli-manned roadblocks at the outskirts of the city, and the cargo must be loaded onto other trucks on the other sides of the roadblocks. In 2002, Israel began building a wall east of the 1967 borders between the West Bank and Israel (referred to hereafter as the wall) causing further disruptions to the WBGS economy.

Stricter external closures have had a devastating impact on sectors of the economy that depend heavily on exports, such as the leather and apparel industries, where employment and output have declined sharply since 2000. The increased frequency of internal closures since 2000 has segmented the WBGS economy. ${ }^{13}$ Trade
Table 2: Trade deficit, earnings of WBGS workers in Israel, and foreign transfers for selected years

$\begin{array}{cccc}\text { Year } & \begin{array}{l}\text { Trade } \\ \text { deficit }\end{array} & \begin{array}{l}\text { Earnings of } \\ \text { WBGS workers } \\ \text { in Israel } \\ \text { (US\$ mn) }\end{array} & \begin{array}{l}\text { Foreign } \\ \text { transfers }\end{array} \\ \text { (US\$ mn) mn) } \\ 1992 & 933 & 930 & 11 \\ 1998 & 1,981 & 661 & 434 \\ 1999 & 2,148 & 687 & 459 \\ 2000 & 1,960 & 601 & 728 \\ 2001 & 1,304 & 179 & 1,000 \\ 2002 & 1,221 & 106 & 1,115 \\ 2003 & 1,627 & 168 & 877 \\ 2004 & 1,965 & 162 & 858\end{array}$

Sources: Diwan and Shaban (1999) for 1992; PCBS-E for1993-2004.

Table 3: Key public finance statistics, 1999-2005

$\begin{array}{crrr}\text { Year } & \begin{array}{l}\text { PA budget } \\ \text { expenditures tax transfers } \\ \text { (US\$ mn) }\end{array} & \begin{array}{l}\text { Isto PA budget } \\ \text { (US\$ mn) }\end{array} & \text { (US\$ mn) } \\ 1999 & 937 & 580 & 0 \\ 2000 & 1,212 & 587 & 54 \\ 2001 & 1,120 & 0 & 532 \\ 2002 & 984 & 72 & 447 \\ 2003 & 1,129 & 471 & 219 \\ 2004 & 1,355 & 617 & 353 \\ 2005 & 1,638 & 757 & 349\end{array}$

Sources: World Bank (2004-A) for 1999-2003; World Bank (2006) for 2004-2005. 


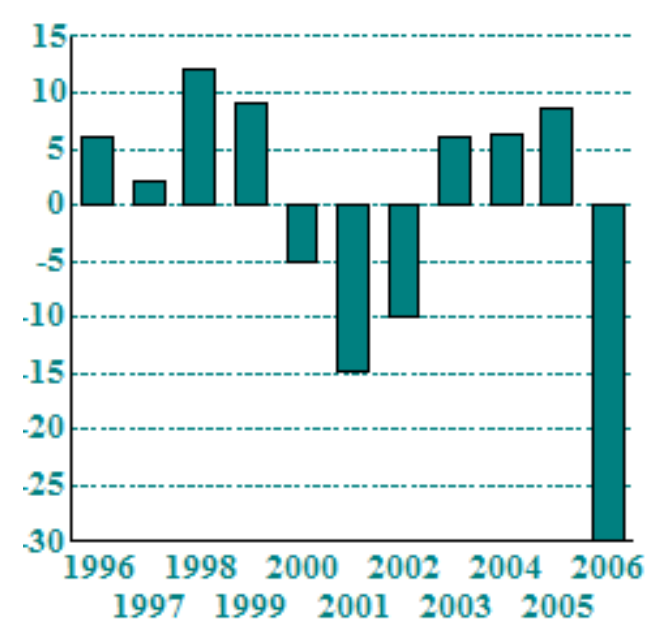

Figure 1: WBGS GDP growth rates, 19962006

Sources: PCBS-A for 1996-1999; World Bank (2006) for 2000-2006.

The construction of the wall has disrupted the lives of more than 200,000 Palestinians and adversely affected the WBGS agricultural sector. While Israel justifies the construction of the wall on the need to separate Israel from the West Bank for security reasons, the wall is being built deep inside the West Bank, creating large restricted zones between the wall and the 1967 Israel-West Bank borders. Once the wall is completed, the restricted zones will account for almost 15 percent of the West Bank. The restricted zones include large irrigated areas, which account for a disproportionate share of WBGS agricultural output. Palestinian access to the restricted zones is being limited to those with special Israeli permits and only through gates that are open for a limited number of hours, making it extremely difficult for Palestinian landowners who live outside a restricted zone to farm their land located in the zones.

Deteriorating economic conditions

The curtailment of access by WBGS workers to the Israeli labor market, the increase in the severity of internal and external closures, Israeli military raids, and other adverse shocks experienced by the Palestinian economy since 2000 have led to a sharp decline in WBGS GDP. In 2006, WBGS GDP and GDP per capita were 21.9 and 30 percent, respectively, below their 1999 levels. ${ }^{14}$ However, GDP has fluctuated widely since 2000 , depending on foreign aid and the severity of closures and other Israeli punitive measures (see Figure 1).
With the loss of job opportunities in Israel and the decline of domestic real GDP, the WBGS unemployment rate has increased enormously since 2001 . For the period 2001-2005, the average unemployment rate was 26.5 percent. The W BGS poverty rate increased dramatically during the same period. Based on an expenditure survey conducted by the PCBS, the average poverty rate in the period 2000-2005 was 47.6 percent. ${ }^{15}$ In contrast, 20.3 percent of W BGS Palestinians lived below the poverty line in 1998, the last pre-intifada year for which comparable data is available. ${ }^{16}$

\section{Foreign aid}

Foreign aid to the WBGS before 1994 was limited to UNRWA, which provided assistance since 1948 to Palestinian refugees displaced when Israel was created, and a few nongovernmental organizations that provided low interest loans. With the signing of the Oslo Accords and subsequent establishment of the PA, the amount and scope of foreign aid increased quickly. Between 1994 and 1999, foreign aid averaged around $\$ 0.5$ billion a year. Most foreign aid in the period 1994-1999 was provided by Western countries. Following the 2000 intifada, there was another sharp increase in foreign aid. The average amount of annual foreign aid since 2001 is about one billion dollars. Arab countries have provided a large share of foreign aid since $2001 .^{17}$

Foreign aid in the period 1994-1999 was used mainly for institution building and infrastructure projects. A large share of funds allocated to institution building in this period was used to finance technical assistance provided by foreign experts. ${ }^{18}$ The effectiveness of such assistance was contingent upon the availability of competent personnel at the PA institution receiving the technical assistance, which was not always the case. Israeli control over WBGS borders and the inability to obtain Israeli approval for infrastructure projects in areas controlled directly by Israel prevented donors from investing in many high priority infrastructure projects, forcing them to settle for projects that had lower social and economic returns. One of the projects that received financial pledges from donors was the construction of a seaport in the Gaza Strip. Such a project has a great potential for alleviating the unemployment problem in the Gaza Strip because of the large number of construction jobs it would create and its importance in promoting investment in export-oriented industries. The Gaza seaport has yet to get off the ground because of Israeli opposition. Other high-priority infrastructure projects include sewage treatment plants and inter-city roads. ${ }^{19} \mathrm{~A}$ number of donor-financed sewage networks built since 1994 in some West Bank cities still lack treatment plants due to the lack of Israeli approval. This has created serious health hazards. Little investment was made in the inter-city road network (which is in poor condition due to neglect by the Israeli occupation authorities in the period 1967-1993) because of the failure to obtain Israeli permits. ${ }^{20}$ Hence, donor-financed investment in the transport sector in the post-Oslo period has been limited mainly to local roads. The lack of investment in inter-city roads is most obvious at city entrances, such as that of Nablus, where local roads are wider and much better 
maintained than the inter-city roads they feed into.

The Israeli freeze on PA tax revenue transfers and the dramatic increase in poverty after the 2000 intifada caused donors to redirect foreign aid funds away from infrastructure projects, and toward financing the PA budget and poverty alleviation programs. ${ }^{21}$ Unlike the period 1994-1999, when PA budgets were financed almost exclusively by tax revenues, decreased economic activity and the Israeli freeze on tax revenue transfers have forced the PA to depend heavily on foreign aid after 2001 . For the period 2001-2005, foreign aid financed 32 percent of the PA budget (Table 3 ). Poverty alleviation programs financed by foreign aid have expanded substantially since 2001. In 2002, almost 1.7 million people in the WBGS received food baskets paid for by foreign aid, ${ }^{22}$ and some households received additional assistance in the form of jobs created by employment generation schemes, micro credit, or cash assistance. Since then, poverty alleviation programs financed by foreign aid have focused mainly on subsistence poverty. ${ }^{23}$ In 2005, 27.2 percent of WBGS households received assistance form anti-poverty programs ${ }^{24}$ and most of the assistance was financed by foreign aid.

Foreign aid received by the WBGS in the post-Oslo period has been more than offset by the cost of closures and other punitive measures taken by Israel. The enormous cost of closures, even before the 2000 intifada, was documented in a 1999 study by Radwan Shaban. The study estimated the cost of closures in the period 1993-1996 at \$2.8 billion, which was more than twice the foreign aid disbursed in this period. ${ }^{25}$ Comparable estimates of the cost of closures and other Israeli punitive actions are not available. However, these cost are obviously larger in value and in relation to foreign aid than the cost of closures during the period 1993-1996.

Additionally, foreign aid may have made it more likely for Israel to take some of the punitive measures it has taken since 2000 , such as the curtailment of the flow of Palestinian labor to Israel and frequent closures, allowing Israel to continue its effective occupation of the WBGS without having to meet some of its obligations as an occupying country under international law. In fact, before 1994, closures were infrequent and the flow of Palestinian labor to Israel was rarely disrupted by the Israeli authorities.

Policy implications

The de-development of the Palestinian economy, which began in 1967 following Israeli occupation of the WBGS, continued in the post-Oslo period. Private investment remained very limited in the period 1994-2000 due to continued political uncertainty, unbalanced trade relation with Israel, and Israeli imposed closures. This kept the WBGS highly dependent on Israel for jobs. With such dependence, the curtailment of the access of Palestinian workers to the Israeli labor market following the 2000 intifada resulted in sharp decreases in unemployment and poverty rates. Punitive actions taken by Israel following the 2000 intifada led to further de-development of the Palestinian economy.

The political environment that has prevailed since the 2000 intifada makes it unlikely that the number of W BGS workers in Israel will return to its 1999 level, even if a permanent settlement of the Palestinian-Israeli conflict is reached. Hence, achieving significant decreases in current WBGS unemployment and poverty rates, and reducing dependence on foreign aid will require a huge private investment. But based on the post-Oslo experience, it is unrealistic to expect substantial private capital flows into the WBGS under a temporary political settlement, such as the one that has been floated by the Israeli government in recent months that calls for creating a temporary Palestinian state in the Gaza Strip and parts of the West Bank located behind the wall. First, a temporary settlement would extend political uncertainty, and it is not realistic to expect massive private investment in an uncertain political environment. Second, under a temporary settlement Israel will likely maintain control of WBGS borders, denying the WBGS direct access to international markets. This would make it extremely difficult to attract investment to export-oriented industries, which represent an important source of economic growth for a small open economy such as the WBGS's. Continued Israeli control over WBGS borders would also limit the ability of the WBGS economy to utilize the resources of diaspora Palestinians, which could play a key role in reviving the Palestinian economy because they account for a disproportionate share of financial and human capital accumulated by Palestinians over the last six decades. Third, if the territories covered by the temporary state are not contiguous, which is likely to be the case based on the planned path of the wall, the WBGS economy will continue to be vulnerable to Israeli-imposed closures. Such vulnerability will be a major obstacle to private investment, as the post-Oslo experience has shown

The massive flow of capital needed to revitalize the Palestinian economy and significantly reduce the extremely high unemployment and poverty rates experienced since 2001 cannot be expected without a permanent settlement of the Palestinian-Israeli conflict that includes a Palestinian state. To attract the investment needed, the Palestinian state needs to have control over its borders in order to take advantage of the resources of diaspora Palestinians and stimulate growth in export-oriented industries. It also has to have control over East Jerusalem, the West Bank shores of the Dead Sea, the Jordan valley, and WBGS water resources. Palestinian control over WBGS water resources and the Jordan valley is essential to reviving the Palestinian agricultural sector. Palestinian control over East Jerusalem and the West Bank shores of the Dead Sea is important for attracting private investment to the tourism sector, which could be a major source of economic growth The West Bank shores of the Dead Sea will enable the Palestinian tourism sector to compete in the thriving health tourism. Sovereignty over East Jerusalem will help revitalize the Palestinian tourism sector by ending Israeli restrictions that since 1967 have reduced the number of Palestinian tour operators, inhibited investment in Eas Jerusalem hotels, and weakened the link between East Jerusalem tourism facilities and 
tourist sites in the rest of the WBGS

In view of the post-Oslo experience, a future Palestinian state can be expected to discontinue the unbalanced customs union currently in place between the WBGS and Israel. The economic benefits of a customs union are derived from the free movement of goods between members. Israel has used security as a justification for maintaining restrictions on Palestinian exports to Israel that were supposed to be lifted under the Oslo Accords. It is unrealistic to expect this behavior to change once a Palestinian state is established, making a customs union an unattractive trade policy option for the Palestinian state. If the Palestinian state is to have a special trade relationship with Israel, which may not necessarily be the case given the traumatic experience of the post-Oslo period, a free trade area presents a more realistic option. Unlike a customs union, a free trade area would allow the Palestinian state to have its own tariff structure that reflects its development needs, and would enable it to have special trade arrangements with Arab countries that may not desire similar arrangements with Israel. A free trade area would also allow the Palestinian state to collect its own import taxes, provided the state has control over its borders, thereby ending the transfer of Palestinian import tax revenues to Israel.

The Palestinian state also cannot be expected to maintain the current currency arrangement between the WBGS and Israel that requires the Israeli currency to be used as legal tender in the WBGS without providing a mechanism to compensate the PA for the seigniorage revenues generated as a result of this requirement. However, Palestinian policymakers will need to be careful in designing an alternative currency arrangement. In view of current economic conditions in the WBGS, there is a need to insulate the monetary authorities from expected political pressure to increase money supply to finance government programs aimed at reducing unemployment and poverty rates, which would create an inflationary environment that would be detrimental to private investment and economic growth. This could be done by issuing a currency under a currency board arrangement that would limit domestic money supply to the availability of reserves denominated in the reserve currency to which the domestic currency is linked.

\section{Conclusion}

It is highly unlikely that the Israeli government will allow the number of WBGS workers in Israel to return to its pre-2000 level. Hence, the revitalization of the Palestinian economy will require huge private investments. But such investment cannot be expected without a permanent settlement of the Palestinian-Israeli conflict that includes a Palestinian state with control over its borders and a strong link with diaspora Palestinians.
Notes

Osama Hamed lectures on economics at Rutgers University in Camden, NJ, U.S.A. He may be reached at hamed@camden.rutgers.edu.

1. In some of these areas, the PA also had security control until 2000.

2. Before the freeze, there had been in place a registration process - initiated by the Jordanian authorities in the West Bank and the Egyptian authorities in the Gaza Strip - aimed at giving landowners who lacked official titles to their land (because of ineffective registrations systems in the past) the opportunity to obtain titles. By the time of the Israeli occupation of the WBGS, 70 percent of the West Bank and 10 percent of the Gaza Strip was still not registered. See Hamed (1995).

3. Israeli bulldozers demolished most of the facilities of this airport soon after the beginning of the 2000 intifada.

4. The ban does not even allow replacing dried-up shallow wells with deeper wells, reducing the number of wells in the WBGS over the years, particularly in the West Bank, where most WBGS underground water resources are located.

\section{World Bank (2004b).}

6. These revenues were not included in the 1967-1993 WBGS budgets administered by the Israeli military.

7. Hamed and Shaban (1993).

8. This estimate was based on a study that covered the period 1970-1987. See Hamed and Shaban (1993).

9. Israel began in 2006 to restrict the flow of currency notes and coins to Gaza Strip banks.

10. All banks operating in the WBGS in 1967 were shut down following Israeli occupation. Until the early 1980 s, only Israeli banks were allowed to operate in the WBGS and the services of these banks were limited mainly to Israeli settlers and other Israeli clients with commercial interests in the WBGS. In the $1980 \mathrm{~s}$, a Gaza Stripbased bank (the Bank of Palestine) was allowed to reopen one of its pre-1967 branches after winning an Israeli court case, and a Jordanian bank (the Cairo Amman Bank) was allowed to re-open one of its West Bank branches. No more non-Israeli bank branches were allowed to open in the WBGS until the early 1999s (Hamed, 


\section{$1995)$.}

\section{Khadr (1999).}

12. The lack of sufficient funds created shortages of some essential supplies at PA institutions, forcing them to cut services. That has been particularly the case for Ministry of Health hospitals and clinics.

13. For more information about the economic and social impact of internal closures, see World Bank (2003) and World Bank (2004a).

14. Calculated from PCBS-A and PCBS-B.

15. Calculated from World Bank (2006).

16. World Bank (2004a).

17. Arab countries contributed $\$ 104$ million of foreign aid disbursements during the period 1994-1996, accounting for 10.4 percent of the total (Diwan and Shaban, 1999). In contrast, the share of Arab countries in total foreign aid disbursement in 2002 was 34.5 percent (World Bank, 2004a).

18. Technical assistance accounted for $\$ 244$ million of foreign aid disbursements in the period 1994-1996, or 16.6 percent of the total (Diwan and Shaban, 1999).

19. For more information about WBGS infrastructure investment needs, see World Bank (2004b).

20. Except for roads that serve Israeli settlements, no new inter-city roads were built in the WBGS during the period 1967-1993. In addition, little investment was made to maintain the existing inter-city road network in this period (see Mody, 1996).

21. In 1999, almost all foreign aid commitments were allocated to infrastructure and institution building. In 2002, infrastructure and institution building accounted for only 17 percent of total foreign aid commitments (World Bank, 2003).

\section{See World Bank (2004a).}

23. The subsistence poverty line assumes a daily per capita consumption of $\$ 1.6$, compared with $\$ 2.3$ for the poverty line (World Bank, 2004a).

24. See PCBS-D.
25. Shaban (1999).

\section{References}

Diwan, I. and R. Shaban, eds. 1999. Development under Adversity. New York and Ramallah: Palestine Economic Policy Research Institute and The World Bank.

Hamed, O. and R. Shaban. 1993. "One-Sided Customs and Monetary Union: the Case of the West Bank and Gaza Strip under Israeli Occupation," in S. Fischer, D. Rodrik, and E. Tuma, eds. The Economics of Middle East Peace. Cambridge, MA: The MIT Press.

Hamed, O. 1996. The Palestinian Banking System, Reality and Potential. Ramallah: Palestine Economic Policy Research Institute.

Khadr, A. 1999. "Fiscal Management," in I. Diwan and R. Shaban, eds. Development under Adversity. New York and Ramallah: Palestine Economic Policy Research Institute and The World Bank.

[MAS] Palestine Economic Policy Research Institute. 2007. Mapping Palestinian Non-Government Organizations in the West Bank and Gaza Strip. Ramallah: MAS.

[MAS] Palestine Economic Policy Research Institute. 2004. Economic Monitor, issue 11. Ramallah: MAS.

Mody, A. 1996. West Bank and Gaza: Infrastructure, Institutions, and Growth. Ramallah: MAS.

[PCBS-A] Palestinian Central Bureau of Statistics. Macro Economic Indicators for the Palestinian Territory at Constant Prices. www.pcbs.gov.ps/Portals/_pcbs/ NationalAcounts [accessed 7 November 2007].

[PCBS-B] Palestinian Central Bureau of Statistics. GDP in Remaining West Bank and Gaza Strip by Economic Activity for the Years 2006, 2007 at Constant Prices. www.pcbs.gov.ps/Portals/_pcbs/NationalAccounts [accessed 7 November 2007].

[PCBS-C] Palestinian Central Bureau of Statistics. Percentage Distribution of Population Aged 15 Years and Over in the PT by Region and Labor Force Status:1995-2000. www.pcbs.gov.ps/_pcbs/labor [accessed 8 November 2007].

[PCBS-D] Palestinian Central Bureau of Statistics. Impact of the Israeli Measures on the Economic Conditions of Palestinian Households (15th Round: October-December, 2005).www.pcbs.gov.ps/Portals/_pcbs/PressRelease/ econcond_15e.pdf [accessed 7 November 2007].

[PCBS-E]. Palestinian Central Bureau of Statistics. Palestinian Balance of Payments in Remaining West Bank and Gaza Strip:1998-2004. www.pcbs.gov.ps/Portals/ _pcbs/Balnce [accessed 7 November 2007].

Shaban, R. 1999. "The Harsh Reality of Closure," in I. Diwan and R. Shaban, eds. Development under Adversity. New York and Ramallah: Palestine Economic Policy Research Institute and The World Bank.

World Bank. 2006. West Bank and Gaza Update, April 2006. 
http;/web.worldbank.org/WBSITE/EXTERNAL/COUNTRIES/MENAEXT//W ESTBANKGAZAEXTN,,menuPK:294389 [accessed 5 May 2008].

World Bank. 2004a. Forty Two Months: Intifada, Closures and Palestinian Economic Crisis. Washington, D.C.: The World Bank.

World Bank, 2004b. West Bank and Gaza Infrastructure Assessment. http//sitesources.worldank.org/W estBankGazaEXTN/Resources.nttp.Infrasruct ureAsssmentdecou.pdf [accessed 13 November 2008].

World Bank. 2003. Twenty Seven Months: Intifada, Closures and Palestinian Economic Crisis. Washington, D.C.: The World Bank. 